\section{Stereospecific \\ Four-Bond Phosphorus-Phosphorus Spin Couplings in Phosphazenyl-Phosphazenes}

\section{Biddlestone*, R. Keat**, H. Rose***,}

D. S. RycrofT**, and R. A. SHAW****

* Department of Chemistry, University of Khartoum, P. O. Box 321, Khartoum, Sudan.

** Department of Chemistry, University of Glasgow, Glasgow, G $128 \mathrm{QQ}$, U. K.

*** Lehrstuhl für Anorganische Chemie I der RuhrUniversität Bochum, D-463 Bochum-Querenburg, Postfach 2148, BRD.

**** Department of Chemistry, Birkbeck College, (University of London), Malet Street, London WC1E $7 \mathrm{HX}, \mathrm{U} . \mathrm{K}$.

(Z. Naturforsch. 31 b, 1001-1002 [1976]; received March 4, 1976)

${ }^{31} \mathrm{P}$ NMR Spectra,

Four-Bond Phosphorus-Phosphorus Coupling, Conformation, Phosphazenylcyclophosphazenes

Four-bond phosphorus-phosphorus coupling constants have been measured from the ${ }^{31} \mathrm{P}$ NMR spectra of phosphazenylcyclophosphazenes. Their magnitude appears to be related to the conformation adopted by the phosphazenyl-group relative to the phosphazene ring.

The two-bond spin-spin coupling constant, ${ }^{2} J_{\underline{P} N \underline{P}}$ is well documented ${ }^{1}$ in both cyclic and acyclic phosphazenes. However, very few four-bond cou-

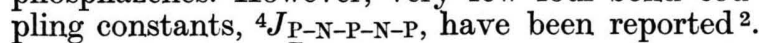

Examination of the ${ }^{31} \mathrm{P}$ NMR spectra of a series of phosphazenyl-derivatives of cyclotriphosphaza-

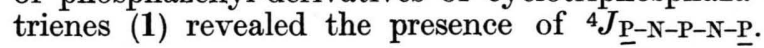

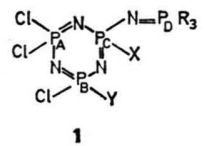

The largest coupling $(7.5 \mathrm{~Hz})$ was in the trimethylphosphazenyl-derivative $(\mathbf{1})^{3}{ }^{3}$ (for numbering see Table) and double and triple resonance experiments were carried out to establish its relative sign. The results are shown in the Figure, where a homonuclear ${ }^{31} \mathrm{P}\left\{{ }^{31} \mathrm{P}\right\}$ experiment (carried out under conditions of proton noise decoupling) showed that $J_{\underline{P}_{A}-\mathrm{N}-\underline{P}_{\mathrm{C}}}$ and $J_{\underline{\mathrm{P}}_{\mathrm{A}}-\mathrm{N}-\mathrm{P}-\mathrm{N}-\underline{P}_{\mathrm{D}}}$ have the same sign. In principle, the same experiment gives the relative

Requests for reprints should be sent to Dr. R. KEAT, Department of Chemistry, University of Glasgow, Glasgow, G 128 QQ, U. K., or

Professor R. A. SHAw, Department of Chemistry, Birkbeck College, (University of London), Malet Street, London, WC 1 E 7 HX, U. K.

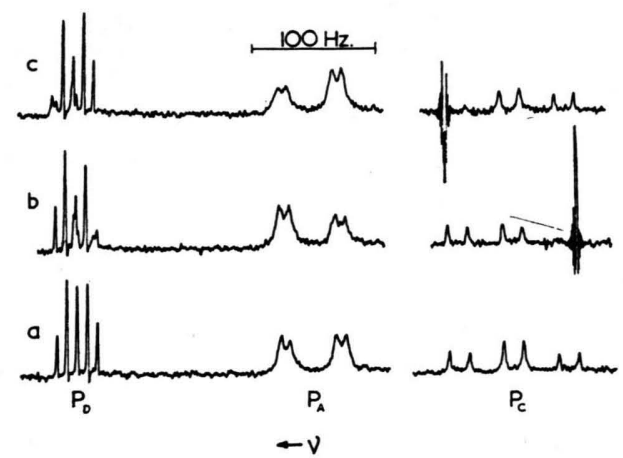

Figure. ${ }^{31} \mathrm{P}$ NMR spectra of $\mathbf{1 a}(\mathrm{R}=\mathrm{Me}, \mathrm{X}=\mathrm{Y}=\mathrm{Cl})$, (a) normal spectrum with complete ${ }^{1} \mathrm{H}$ decoupling, (b) and (c) as in (a), but with irradiation of $\mathrm{P}_{c}$ signals (see text).

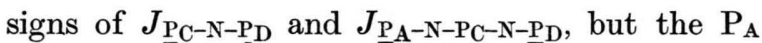
resonance is broad (presumably because of quadrupolar relaxation of adjoining nitrogen and/or chlorine nuclei) and this combined with intensity changes, caused by population transfer effects, and the weakness of the available phosphorus irradiation field $\left(\frac{\gamma\left({ }^{31} \mathrm{P}\right) \mathrm{B}_{2}}{2 \pi}<4 \mathrm{~Hz}\right)$ meant that interpretable effects could not be observed. However, selective irradiation of $\mathrm{P}_{\mathrm{A}}$ and observation of $\mathrm{P}_{\mathrm{D}}$ showed that $J_{\underline{P}_{A}-\mathrm{N}-\underline{P}_{\mathrm{C}}}$ and $J_{\underline{P}_{\mathrm{C}-\mathrm{N}-\underline{\mathrm{P}}_{\mathrm{D}}} \text { had the same sign. There is }}$ good reason to believe that $J_{\mathrm{P}-\mathrm{N}-\mathrm{P}}$ will be positive ${ }^{1,4}$, so that the four bond coupling is also positive. This was confirmed by examination of the ${ }^{1} \mathrm{H}$ spectrum of this compound which consists of a doublet of doublets: ${ }^{1} \mathbf{H}\left\{{ }^{31} \mathrm{P}\right\}$ double resonance showed that $J_{\underline{\underline{P}}-\mathrm{N}-\underline{\underline{P}}}$ and $J_{\underline{\underline{P}}-\mathrm{N}-\mathrm{P}_{\mathrm{D}}-\mathrm{C}-\underline{\mathrm{H}}}$ have the same sign and that $J_{\underline{\mathrm{P}} \mathrm{C}-\mathrm{N}-\underline{\mathrm{P}}_{\mathrm{D}}}$ and $J_{\underline{\mathrm{P}} \mathrm{D}-\mathrm{C}-\underline{\mathrm{H}}}$ are of opposite sign, the latter generally being found to be negative in phosphorus $(V)$ compounds ${ }^{5}$. Homonuclear ${ }^{31} \mathrm{P}\left\{{ }^{31} \mathrm{P}\right\}$ experiments on the compounds ${ }^{3,6}$ listed in the Table showed that the four-bond couplings are positive, with the exception of that for $1 \mathrm{e}$ where $J_{\underline{\mathrm{P}}_{\mathrm{A}}-\mathrm{N}-\mathrm{P} \mathrm{C}-\mathrm{N}-\underline{P}_{\mathrm{D}}}$ is $-0.4 \mathrm{~Hz}$.

The hitherto reported $\underline{\mathrm{P}}-\mathrm{N}-\mathrm{P}$ couplings in cyclophosphazenes are not simply related to the electronegativity of the substituents on the phosphorus atoms ${ }^{1}$ and the same generalisation may be made for $J_{\underline{P}_{A}-\mathrm{N}-\mathrm{PC}}$ and $J_{\underline{P}_{A}-\mathrm{N}-\mathrm{P} C-\mathrm{N}-\underline{P}_{\mathrm{D}}}$ (Table). For example, the four-bond coupling becomes less positive in the order $\mathrm{X}=\mathrm{Cl}>\mathrm{OEt}>\mathrm{NMe}_{2}>\mathrm{Ph}$. However, there is evidence to suggest that this coupling constant is related to the preferred conformation adopted by the phosphazenyl-group relative to the phosphazene ring. The crystal structure of $1 \mathbf{e}^{7}$ shows that the plane containing the exocyclic $\mathrm{P}-\mathrm{N}-\mathrm{P}$ unit lies perpendicular to the plane containing the phosphazene ring (type II conformation $\left.^{8}\right)$, but in $\mathbf{1}(\mathrm{R}=\mathrm{Ph}, \mathrm{X}=\mathrm{Cl}, \mathrm{Y}=\mathrm{Cl})^{9}$, and in 2-trans-6- $\mathrm{N}_{4} \mathrm{P}_{4} \mathrm{Cl}_{6}\left(\mathrm{~N}=\mathrm{PPh}_{3}\right)_{2}{ }^{10}$, the $\mathrm{Ph}_{3} \mathrm{P}=$ $\mathrm{N}$-group is rotated by approximately $90^{\circ}$ (type $\mathrm{I}$ 
Table. ${ }^{31} \mathrm{P}$ NMR data ${ }^{\mathrm{a}}$ for phosphazenylcyclophosphazenes.

\begin{tabular}{|c|c|c|c|c|c|c|c|c|}
\hline \multirow{2}{*}{$\frac{\text { Compound }}{\mathbf{1 a}}$} & \multirow{2}{*}{$\frac{\mathrm{R}}{\mathrm{Me}}$} & \multirow{2}{*}{$\frac{\mathrm{X}}{\mathrm{Cl}}$} & \multirow{2}{*}{$\frac{\mathrm{Y}}{\mathrm{Cl}}$} & \multicolumn{2}{|l|}{$\delta_{\mathrm{P}^{\mathrm{b}}}$} & \multicolumn{2}{|c|}{$J_{\underline{\mathrm{P}-\mathrm{N}-\underline{\mathrm{P}}}}(\mathrm{Hz})^{\mathbf{c}}$} & \multirow{2}{*}{$\frac{J_{\underline{\text { P}}-\mathrm{N}-\mathrm{P}-\mathrm{N}-\underline{\mathrm{P}}}(\mathrm{Hz})^{\mathrm{d}}}{\mathrm{P}_{\mathrm{A}} \ldots \mathrm{P}_{\mathrm{D}}+7.5^{\mathrm{e}}}$} \\
\hline & & & & $\begin{array}{l}\mathrm{A}(=\mathrm{B}) \\
\mathrm{C} \\
\mathrm{D}\end{array}$ & $\begin{array}{r}20.9 \\
1.1 \\
25.4\end{array}$ & $\begin{array}{l}\mathrm{P}_{\mathrm{A}} \ldots \mathrm{P}_{\mathrm{C}} \\
\mathrm{P}_{\mathrm{C}} \ldots \mathrm{P}_{\mathrm{D}}\end{array}$ & $\begin{array}{l}44.5 \\
16.0\end{array}$ & \\
\hline $1 \mathrm{~b}$ & $\mathrm{Ph}$ & $\mathrm{Cl}$ & $\mathrm{Cl}$ & $\begin{array}{l}\mathrm{A}(=\mathrm{B}) \\
\mathrm{C} \\
\mathrm{D}\end{array}$ & $\begin{array}{r}20.3 \\
0.2 \\
15.4\end{array}$ & $\begin{array}{l}\mathrm{P}_{\mathrm{A}} \ldots \mathrm{P}_{\mathrm{C}} \\
\mathrm{P}_{\mathrm{C}} \ldots \mathrm{P}_{\mathrm{D}}\end{array}$ & $\begin{array}{l}47.5 \\
27.8\end{array}$ & $\mathrm{P}_{\mathrm{A}} \ldots \mathrm{P}_{\mathrm{D}}+3.4$ \\
\hline $1 \mathrm{e}$ & $\mathrm{Ph}$ & OEt & $\mathrm{Cl}$ & $\begin{array}{l}\mathrm{A}(=\mathrm{B}) \\
\mathrm{C} \\
\mathrm{D}\end{array}$ & $\begin{array}{r}18.5 \\
-1.6 \\
13.5\end{array}$ & $\begin{array}{l}\mathbf{P}_{\mathbf{A}} \ldots \mathbf{P}_{\mathbf{C}} \\
\mathbf{P}_{\mathrm{C}} \ldots \mathbf{P}_{\mathbf{D}}\end{array}$ & $\begin{array}{l}49.5 \\
39.0\end{array}$ & $\mathrm{P}_{\mathrm{A}} \ldots \mathrm{P}_{\mathrm{D}}+0.9$ \\
\hline 1d & $\mathrm{Ph}$ & $\mathrm{NMe}_{2}$ & $\mathrm{Cl}$ & $\begin{array}{l}\mathrm{A}(=\mathrm{B}) \\
\mathrm{C} \\
\mathrm{D}\end{array}$ & $\begin{array}{r}17.1 \\
4.3 \\
13.6\end{array}$ & $\begin{array}{l}\mathbf{P}_{\mathrm{A}} \ldots \mathrm{P}_{\mathrm{C}} \\
\mathrm{P}_{\mathrm{C}} \ldots \mathrm{P}_{\mathrm{D}}\end{array}$ & $\begin{array}{l}36.8 \\
28.4\end{array}$ & $\left|\mathrm{P}_{\mathrm{A}} \ldots \mathrm{P}_{\mathrm{D}}\right|<0.1$ \\
\hline $1 \mathrm{e}$ & $\mathrm{Ph}$ & $\mathrm{Ph}$ & $\mathrm{Cl}$ & $\begin{array}{l}\mathrm{A}(=\mathrm{B}) \\
\mathrm{C} \\
\mathrm{D}\end{array}$ & $\begin{array}{r}16.1 \\
2.9 \\
14.4\end{array}$ & $\begin{array}{l}\mathbf{P}_{\mathrm{A}} \ldots \mathrm{P}_{\mathrm{C}} \\
\mathrm{P}_{\mathrm{C}} \ldots \mathrm{P}_{\mathrm{D}}\end{array}$ & $\begin{array}{r}21.9 \\
5.8\end{array}$ & $\mathrm{P}_{\mathrm{A}} \ldots \mathrm{P}_{\mathrm{D}}-0.4$ \\
\hline 1f & $\mathrm{Ph}$ & $\mathrm{Cl}$ & $\mathrm{NMe}_{2}$ & $\begin{array}{l}\text { A } \\
\text { B } \\
\text { C } \\
\text { D }\end{array}$ & $\begin{array}{r}21.4 \\
26.4 \\
4.4 \\
14.6\end{array}$ & $\begin{array}{l}\mathrm{P}_{\mathrm{A}} \ldots \mathrm{P}_{\mathrm{B}} \\
\mathrm{P}_{\mathrm{A}} \ldots \mathrm{P}_{\mathrm{C}} \\
\mathrm{P}_{\mathrm{B}} \ldots \mathrm{P}_{\mathrm{C}} \\
\mathrm{P}_{\mathrm{C}} \ldots \mathrm{P}_{\mathrm{D}}\end{array}$ & $\begin{array}{l}42.8 \\
57.4 \\
57.0 \\
26.2\end{array}$ & $\begin{array}{l}\mathrm{P}_{\mathrm{A}} \ldots \mathrm{P}_{\mathrm{D}}+5.5 \\
\mathrm{P}_{\mathrm{B}} \ldots \mathrm{P}_{\mathrm{D}}+\mathbf{3 . 3}\end{array}$ \\
\hline \multicolumn{4}{|c|}{ 2-trans-6- $\mathrm{N}_{4} \mathrm{P}_{4} \mathrm{Cl}_{6}\left(\mathrm{~N}=\mathrm{P}_{\mathrm{D}} \mathrm{Ph}_{3}\right)_{2}$} & $\mathrm{D}$ & 13.8 & & & $\left|\mathrm{P}_{\mathrm{D}}-\mathrm{N}-\mathrm{P}-\mathrm{N}-\mathrm{P}\right| 4.6^{\mathrm{f}}$ \\
\hline
\end{tabular}

a Obtained on a Varian XL-100 in the C. W. mode at $40.5 \mathrm{MHz}$ in $\mathrm{CDCl}_{3}$ solution at ca. $25^{\circ}$.

b Relative to $85 \% \mathrm{H}_{3} \mathrm{PO}_{4}$; low field shifts are positive.

c All couplings are positive, $\pm 0.5 \mathrm{~Hz}$.

d $\pm 0.1 \mathrm{~Hz}$.

e $\bar{J}_{\underline{P}^{-}-{ }^{-}-\underline{H}}=-13.02 \mathrm{~Hz}, J_{\underline{P}^{-N}-P_{D^{-C}-\underline{H}}}=+0.65 \mathrm{~Hz}$.

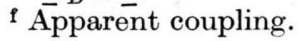

conformation $^{8}$; see ref. $\left.{ }^{9}\right)$. Furthermore, basicity measurements on a series of phosphazenylcyclophosphazenes indicate that electron supply from the $\mathrm{Ph}_{3} \mathrm{P}=\mathrm{N}$-group to the cyclophosphazene ring is more effective in $\mathbf{1 b}$ and $\mathbf{1 f}$ than in $\mathbf{1 d}, \mathbf{1 e}$ or $1 \mathrm{c}$ (at least on protonation). The smaller, or least positive, four bond couplings may therefore be correllated with a preferred conformation in which the plane containing the exocyclic $\mathrm{P}-\mathrm{N}-\mathrm{P}$ unit is approximately perpendicular to the plane containing the phosphazene ring. The relatively inefficient electron supply to the cyclophosphazene ring in this conformation would be consistent with a reduced

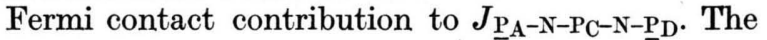

${ }^{1}$ E. G. Finer and R. K. Harris, Progress in NMR Spectroscopy 6, 86 [1970]; R. Keat, R. A. Shaw, and M. Woops, J. Chem. Soc. Dalton, in press.

2 G. R. Feistel and T. Moeller, J. Inorg. Nucl. Chem. 29, 2731 [1967]; M. Biddlestone and R. A. Shaw, J. Chem. Soc. (A) 1971, 2715; H. W. Roesky, Chem. Ber. 105, 1439 [1972].

$3 \mathrm{H}$. Rose and R. A. Shaw, unpublished results.

4 P. Clare, D. B. Sowerby, R. K. Harris, and M. M. WAZEer, J. Chem. Soc. Dalton 1975, 625.

5 W. McFarlane, Proc. Roy. Soc. (London) A 306, 185 [1968]. reduction in this coupling is paralleled by a progressive high-field shift for the $\mathbf{P}_{A}$ signals. This trend in ${ }^{31} \mathrm{P}$ shifts is often observed with increasing chlorine content of aminochlorocyclophosphazenes, where the phosphorus atoms become progressively more electron deficient.

It is interesting, but perhaps surprising, in view

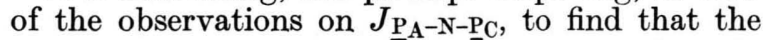
positive two bond coupling, $\bar{J}_{\mathrm{PC}-\mathrm{N}-\mathrm{P}_{\mathrm{D}}}$, is linearly related to electronegativity parameters for the $\mathrm{X}$-substituents in $\mathbf{1 b}-\mathbf{1 e}$.

R. K. and D. S. R. thank the S. R. C. (U. K.) for assistance in the purchase of NMR equipment.

6 M. Biddlestone and R. A. Shaw, J. Chem. Soc. Dalton 1973, 2740.

7 M. Biddlestone, G. J. Bullen, P. E. Dann, and R. A. Shaw, Chem. Commun. 1974, 56.

8 R. A. Shaw, Pure Appl. Chem. 44, 317 [1975]; Z. Naturforsch. 31 b, 641 [1976].

9 Y.S. Babu, T. S. Cameron, S. S. Krishnamurthy, H. MANOHAR, and R. A. Shaw, Z. Naturforsch. 31 b, 999 [1976].

10 G. J. BULLEN and P. E. DANN, unpublished results.

11 M. Biddlestone, S. N. Nabi, and R. A. Shaw, J. Chem. Soc. Dalton 1975, 2634. 